\title{
Field Adaptation for Watermelon Cultivation under Shallow Ground Water Table in Tidal Lowland Reclamation Area
}

\author{
Momon Sodik Imanudin, Satria JP, Bakri and M. Edi Armanto \\ Faculty of Agriculture, Sriwijaya University South Sumatra, Indonesia
}

\begin{abstract}
Agriculture productivity of tidal lowland reclamation areas in South Sumatra is still low. It leads to the increasing of agricultural land conversion into plantation areas. Controlling the water table is the main factor in the tidal lowlands; this research aimed to develop micro drainage system in tertiary block for controlling water table under wet condition. Watermelon was used as a crop indicator and planted in midMarch 2015. The location of the research was in a tidal lowland agriculture with land typology B, a land where the tide can only be as irrigation during the rainy season. The method of this research was surveying and monitoring. Groundwater observation, measurement value hydraulic conductivity and land drainage applications were included in the field activities. The design of land drainage used an intensive shallow drainage concept; the effect of the depth of the water table to water status was evaluated by the UPFLOW model. A micro drainage on tertiary block was used by $8 \mathrm{~m}$ drain spacing, with channel depth of $20 \mathrm{~cm}$. The results showed that the tertiary gate operation was maximum drainage option. The water table depth was $25 \mathrm{~cm}$ in soil depth. The watermelon crops grew well and production reached $20 \mathrm{t} \mathrm{ha}^{-1}$.
\end{abstract}

Key words: drainage; tidal lowland; water table; watermelon

\section{INTRODUCTION}

Increaseing food production becomes essential to meet the population growth. Rice production in Indonesia has so far been supplied by swampland areas, including outside of Java island like Sumatera island (Shultz, 2016). A problem occurs when there is a decrease in soil quality and more over there are many lands change their function to plantation (Aswandi et al., 2017). Such land conversion caused negative impacts to the soil, like decreasing biophysical soil conditions for paddy production and damaging infrastructure network of water system. Currently only $45 \%$ of the tidal lowland in Telang II Banyuasin (South Sumatera) is cultivated to food crops (Imanudin et al., 2010). Therefore, the agricultural development in tidal lowland reclamation areas should take into account the physical and environmental conditions, so the value of the investment is proportional to the

\footnotetext{
Correspondence Author: Momon Sodik Imanudin. Soil and Water Conservation Laboratory, Department of Soil Science, Faculty of Agriculture, Sriwijaya University, Indonesia, Email: momon_unsri@yahoo.co.id
}

profit earned and the sustainability of food agriculture is maintained (Zhu et al., 2017).

In other places in Sumatera, oil palm profits are able to be overcome by intensive farming models of food crops if tidal lowland is equipped with infrastructure network of water system. This tidal lowland is able to be planted three times per year with the pattern of paddy-corn-corn. This condition can generate higher income than oil palm cultivations (Imanuddin \& Bakri, 2014). This report suggests that economic values is considered as crop diversification effort.Watermelon is one of the potential crops for crop diversification. This crop has a high economic value because of the high demands for domestic consumption. Watermelon cultivation in upland can double the income compare to paddy crops. While watermelon cultivation in Iran under full irrigation water requirement got high production of $37.45 \mathrm{t} \mathrm{ha}^{-1}$ per year (Barzegar et al., 2017). It is also reported that the condition is very potential in tidal lowland after paddy. Watermelon cultivation on 0.5 ha of lowland gave Benefit Cost Ratio (B/C) of 3.76 while for paddy crops showed $B / C$ just 
1.57. The same research on watermelon in Iran showed the average yield value of $\mathrm{B} / \mathrm{C}$ of 2.61 (Nosetto et al., 2009; Asri et al., 2012).

Watermelon is commonly planted in upland. Second crop cultivation of tidal lowland needs some efforts to reduce soil wetness level in the rooting zone for reducing groundwater table. This main problem in watermelon cultivation on tidal lowlands is a shallow groundwater table condition. The production can fall upto $20-50 \%$ when the ground water level is too shallow (about 10$20 \mathrm{~cm}$ under the soil surface). The very shallow water level can decline production because it disturbs plant growth and root respiration (Nosetto et al., 2009). However, the depth of the ground water level should not be deeper than $100 \mathrm{~cm}$. These conditions contributed sufficient capillary water to meet the needs of crop evapotranspiration. A research on sandy loam soil showed a significant contribution of groundwater capillary in $70 \mathrm{~cm}$ depth below the soil surface. In this condition $80 \%$ of the crop water requirement can be supplied from groundwater capillarity (Udom et al., 2013). China is the largest watermelon producer in the world; approximately $68 \%$ of total world production. However, the highest watermelon production reached $76.3 \mathrm{tha}^{-1}$ in Turkey with irrigation level of $342 \mathrm{~mm}$ and the water needs for evapotranspiration was $412 \mathrm{~mm}$ (Erdem et al., 2005).

The design of land drainage in South Sumatera was done with intensive shallow drainage methods (Imanudin at al., 2010). Shallow drainage system was also capable to reduce nitrogen loss due to leached up to 35 $\%$ (Helmers, Christianson, Brenneman, Lockett, \& Pederson, 2012). The applications of water table control in the shallow drainage and sub irrigation system could reduce nitratenitrogen losses by $71 \%$ (Bonaiti \& Borin, 2010). In general, maintaining water table under $30 \mathrm{~cm}$ is commonly suitable for food crop except for paddy. However, the controlled drainage is also important to plush out the toxics element under root zone in tidal lowland areas.

This research aimed to determine the water melon respond under shallow water table condition. The information is useful for farmer to manage the land regarding the time planting and how to reduce the excess water in the field. Gate operation in tertiary canal also will determine to develop the model operation for field water management.

\section{METHODOLOGY}

The research was done in the tidal lowlands of Telang II Primer 17, Mulya Sari village, Banyuasin District, South Sumatra (Indonesia) at the end of rainy season 2015. A field experiment was conducted on tertiary blocks in an area of 0.5 ha. The water system network was completed by water gates at both secondary and tertiary blocks. The condition of water gates properly worked to retain and drain out water. The watermelon was planted from the middle of March to May 2015. Watermelon cultivation (Citrullus vulgaris Schard) uses varieties of Red Top 2.12. Plants Characterized by round fruit and age at harvest is 60 days after planting. The planting system is by planting a dual system that uses a spacing of $90-100 \mathrm{~cm} \times 8 \mathrm{~m}$.

The methodology of the research is field experiment. Watermelon was planted in beds with around $8 \mathrm{~m}$ spacing between the channels. The water in channel were between $20 \mathrm{~cm}$ and $30 \mathrm{~cm}$. The shallow drainage system was used for water control model in tertiary channel. The drainage system did not stimulate pyrite oxidation because the pyrite $\left(\mathrm{FeS}_{2}\right)$ was found in the depths ranged from $70-90 \mathrm{~cm}$ below the soil surface. The scheme of this research was presented in Fig. 1. The observed parameters were soil texture, soil hydraulic conductivity, $\mathrm{pH}$ values as well as the growth and production parameters of watermelon. Soil fractions (clay, silt and sand) were determined by using hydrometer method. The saturated soil hydraulic conductivity (Ksat) was determined by auger hole method 


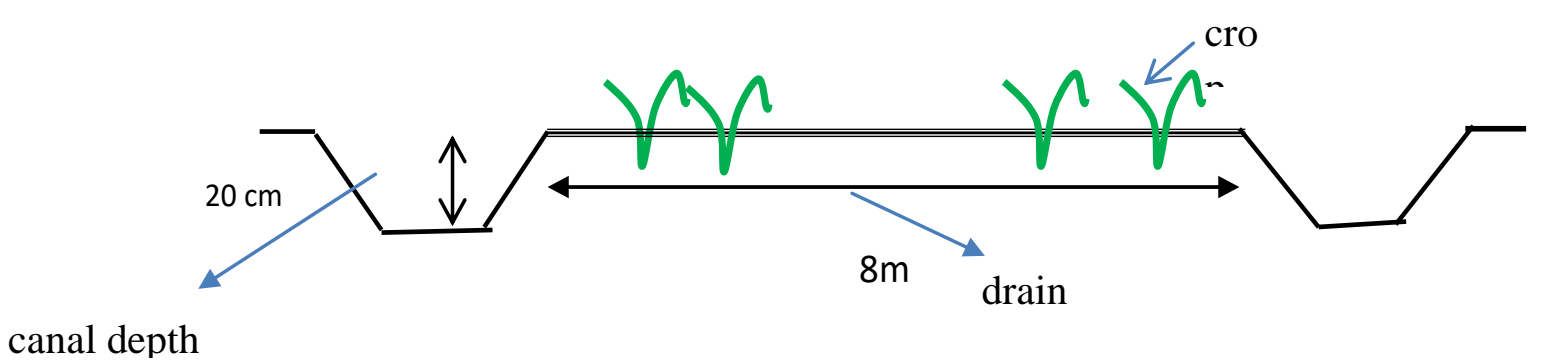

Figure 1. Micro drainage design scheme in the fields

within nine replication ( $\mathrm{T} 1$ to $\mathrm{T} 9$ ), soil reaction $(\mathrm{pH})$ was measured directly in the field by using $\mathrm{pH}$ paper.

Reclamation of tidal lowlands area in South Sumatra begins by making the navigation channel (primary channel) which connects the river that flows in the reclaimed delta. Perpendicular to the primary channel, secondary channel was built, this channel as a secondary plot boundary area of 270 ha. From the secondary channel, the water was carried out through tertiary channels. Two tertiary channels were bordered the area of 16 ha tertiary block. In tertiary and secondary channels were equipped with water gates. The water table was controlled by operating the tertiary water gates as drainage option.

Land drainage system was an open system, the water in the channel was maintained with water gates operating both in the secondary and tertiary levels (Fig. 2 and Fig. 3). Water gates in secondary channels were screw types (sliding gate), so they were operated occasionally. The main goal of secondary water gate operation was to remove excess water during floods (water gates open $60 \mathrm{~cm}$ ) and hold back the tide in case of saltwater intrusion. In the field experiment, there were no water gate operations at the secondary level. It meant that no excess water in the secondary channel, due to the water supply from tide and rain was lower than the maximum capacity of water storage in channel. Free water flow through the gate during high and low tide in the canal was maintained by opening the gate at $60 \mathrm{~cm}$ depth.

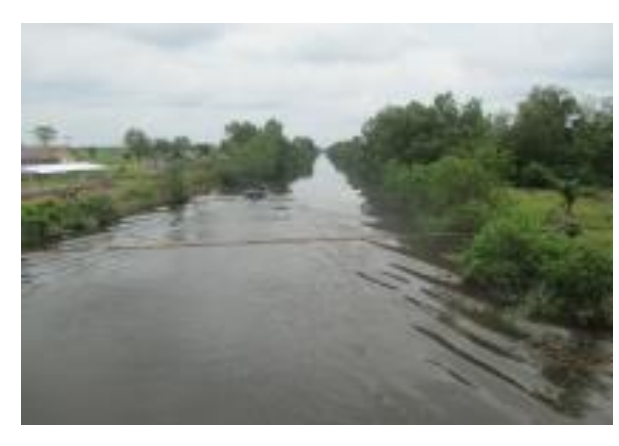

A. primary canal

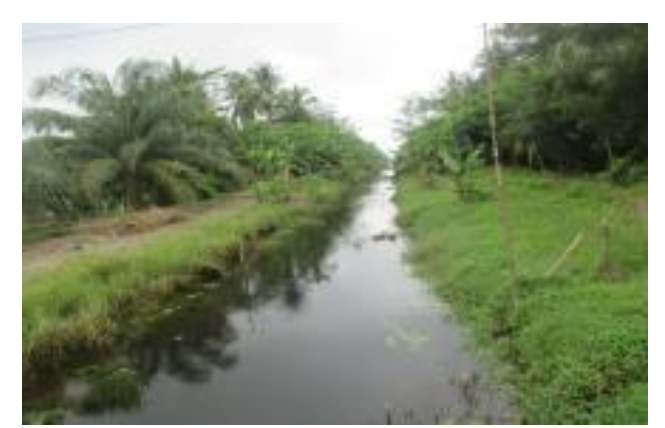

B. Secondary canal

Figure 2. Macro system drainage canal in tidal lowland of Telang II reclamation areas 


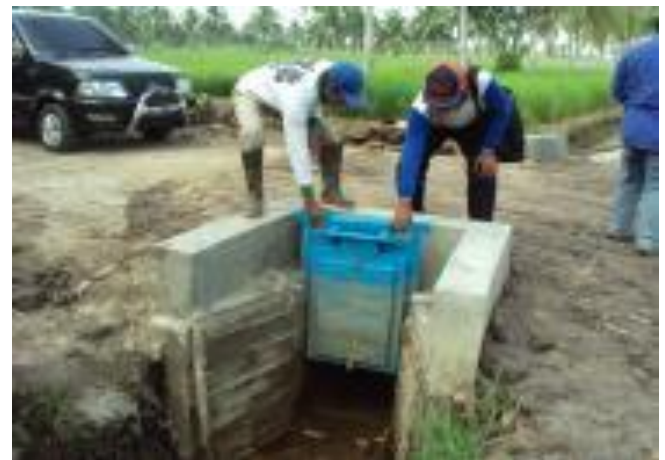

A. Tertiary gate

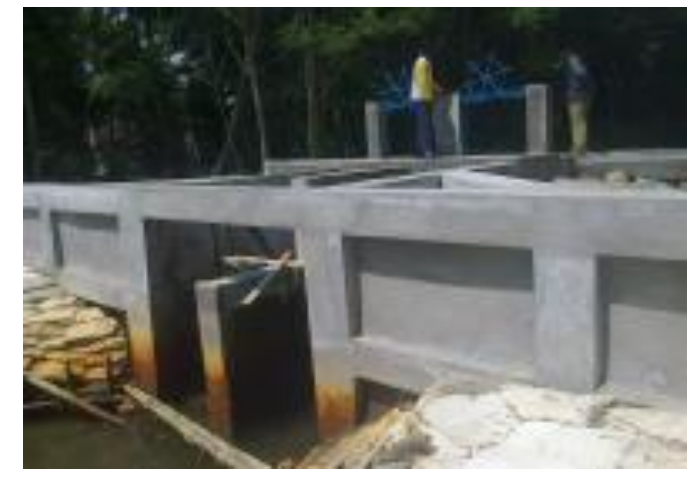

B. Secondary gate

Fig. 3. Secondary hydraulic structure for water control in the field

Controlling water levels was done at the tertiary level. This condition occurred mainly in the rainy season. Tertiary water gate (Fig 4) was a valve type in which the water gate opened and closed automatically as a function of height difference of water levels. When the gate installed in the front (facing to secondary channel), the water from tide was protected automatically, and water in tertiary canal was only drained during low tide.

Water level control was done by operating of the tertiary water gate. The operating gate in tertiary canal had two operating systems; open or close. In this case

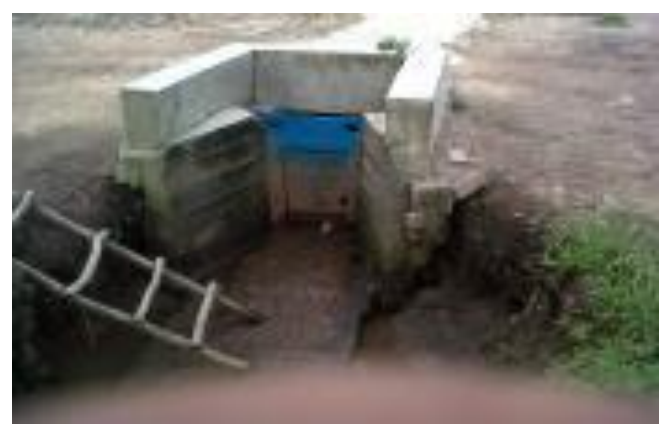

A. Water supply position the water gate was operated for drainage, which was placed in front of the water gate position (estuary). This water gate will open when the water flowing from the tertiary channels (low tide), so the water in the tertiary canal flows into the secondary channel (Fig. 4). When there is a high tide, the water enters the secondary channel, then the water will be held back by the flow of the tide against the water gate so it closes automatically. As a result, if the tide does not come in, so the water supply in the land only from rainfall and the land will not flood although there is a rain.

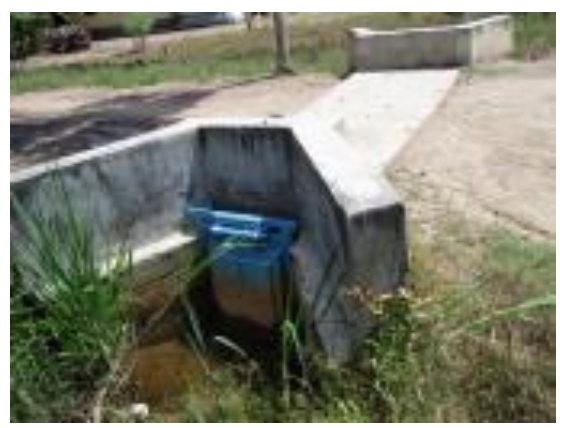

B. Water drainage position

Figure 4. Tertiary hydraulic structure for water table control in tertiary 
The water contribution from capillary rise was estimated using UPFLOW model which was developed to estimate water depth for the capillary rise under land use, soil types and some environmental conditions. The software was able to be adapted with modification in local climatic requirements (Raes, de Nys, \& Deproost, 2002). It was successfully used under tropical wetland condition (Imanudin et al., 2010).

Table 3 shows that the tertiary water gate operatees during plant growth. In the initial stage when the rain was high, the water management objective was to maintenance the dryness. However for the next growing stage, water supply from rain was not much, then gate did not operate (gate could be removed). Free operation meant that the water could enter to the tertiary canal during the tide and drain at low tide. By this operating, it is possible to maintain the constant water level in the root zone. The potential of land drainage in tertiary block was identified by the hourly observation of water level in the secondary and tertiary channels for $2 \times 24$ hours, on 22 to 24 November 2014.

Table 3. Monthly operation of tertiary gate for watermelon cultivation in tidal lowland

\begin{tabular}{lll}
\hline Growing stage & Time Period & Gate Operation/Position \\
\hline Initial stage & April-May & Drainage/In front site \\
Vegetative stage & May-June & Free operation \\
Generative stage & June & Free Operation \\
\hline
\end{tabular}

\section{RESULTS AND DISCUSSION}

\section{Soil Characteristics}

The study area has land typology of B characteristics and the land only receives tide during rainy season and relatively poor in soil drainage. However, it is never stagnant with water for a long time. Only at the time of high tide and heavy rain, the land will be inundated for 3-5 hours. An improvement of drainage system has succeeded in creating an un-flooded land, but the ground water level is still relatively shallow. The measurement of soil hydraulic conductivity in the field shows that classes are in range from 4.1- 5.8 $\mathrm{m}$ per day or $5,800 \mathrm{~cm}$ per day (Table 1 ).

The soil texture is dominated by loam texture, just a few points in first layer have dusty loam, sandy loam and clayey loam textures. Loam ttexture is a transition between sand and clay texture. It is regarded as optimal for crop growth and agricultural production, because it is able to hold water and nutrients better than sand soil texture,

Journal of Wetlands Environmental Management whereas the drainage, aeration and soil properties of the top soils better than clay soils. The ability of capillary water on three types of soil texture is calculated by using the model UPLOW (Table 2).

Table 2 shows the value of soil moisture in different depths of soil. For loam texture, soil saturated water content is about $45 \%, 32$ $\%$ from field capacity and permanent wilting point was $10.3 \%$. From the field condition, the crop should be irrigated when the groundwater was at $60.0 \mathrm{~cm}$ depth below the soil surface and for the sandy loam, moisture content should be $42 \%$ and for saturated condition, moisture content was $21.7 \%$ at the field capacity and the permanent wilting point of around $10 \%$. The crops need irrigation when soil water depth exceeds 50 $\mathrm{cm}$. For the clay loam texture, the soil has water retention characteristics of $51 \%$ for saturated water content, water content of 40 $\%$ for field capacity, and $21 \%$ for moisture content of permanent wilting point. Contribution of groundwater shows that the crop still needs to be watered when the soil 
was in water depths of $70 \mathrm{~cm}$. Contribution of groundwater decreases as the shallow groundwater to the surface position (Table 2).

Water table under the silty clay loam soil texture contributed $90.0 ; 41.0$, and $7.0 \%$ to Evapotranspiration (ET) for water table depths of $50 \mathrm{~cm} ; 100 \mathrm{~cm}$ and $150 \mathrm{~cm}$ respectively, and 92.0; 31.0; $9.0 \%$ for fine sandy loam. A shallow water table caused negative effects on crops. The main problem in the cultivation of such tidal lowlands is the condition of shallow groundwater. Production could fall into range of 20-50\% if the ground water was too shallow at level of 10-20 cm under the soil surface (Rizzo et al, 2018).

Table 1. Field measurement of hydraulic conductivity using auger hole method

\begin{tabular}{|c|c|c|c|c|c|c|c|c|c|c|}
\hline \multirow{2}{*}{$\mathbf{N r}$} & \multirow{2}{*}{ Replications } & \multicolumn{9}{|c|}{ K (Saturated Hydraulic Conductivity) Values $\left(\mathrm{m} \mathrm{day}^{-1}\right)$} \\
\hline & & T1 & $\mathbf{T 2}$ & T3 & T4 & T5 & T6 & T7 & T8 & T9 \\
\hline 1 & $\mathrm{U} 1$ & 5.64 & 5.32 & 5.46 & 5.67 & 5.71 & 5.81 & 6.02 & 5.93 & 5.84 \\
\hline 2 & $\mathrm{U} 2$ & 4.40 & 4.75 & 4.43 & 4.65 & 5.46 & 4.53 & 5.46 & 5.04 & 5.07 \\
\hline 3 & $\mathrm{U} 3$ & 4.16 & 4.73 & 4.46 & 4.44 & 4.55 & 4.57 & 4.44 & 5.13 & 5.20 \\
\hline & Average & 4.73 & 4.93 & 4.78 & 4.92 & 5.24 & 4.97 & 5.31 & 5.37 & 3.37 \\
\hline
\end{tabular}

Remarks: T1-T9: Treatment 1-9; source: Field measurement (2015)

Table 2. Contributions of capillary water to soil water content on the root zone

\begin{tabular}{|c|c|c|c|}
\hline \multirow{2}{*}{$\begin{array}{l}\text { Water } \\
\text { depth } \\
(\mathbf{c m})\end{array}$} & \multicolumn{3}{|c|}{$\begin{array}{c}\text { Contributions of capillary water and soil water content on the root zone for } \\
\text { some texture classes }(\%)\end{array}$} \\
\hline & Loam & Sandy loam & Clay loam \\
\hline 10 & $0.0 \mathrm{~mm} \mathrm{day}^{-1}(44.8 \%)$ & $0.0 \mathrm{~mm} \mathrm{day}^{-1}(41.7 \%)$ & $0.0 \mathrm{~mm} \mathrm{day}^{-1}(50.8 \%)$ \\
\hline 20 & $0.0 \mathrm{~mm}^{-1} \mathrm{day}^{-1}(44.2 \%)$ & $0.0 \mathrm{~mm} \mathrm{day}^{-1}(40.8 \%)$ & $0.1 \mathrm{~mm} \mathrm{day}^{-1}(49.8 \%)$ \\
\hline 30 & $0.1 \mathrm{~mm} \mathrm{day}^{-1}(43.4 \%)$ & $1.0 \mathrm{~mm} \mathrm{day}^{-1}(39.6 \%)$ & $0.2 \mathrm{~mm} \mathrm{day}^{-1}(49.0 \%)$ \\
\hline 40 & $0.3 \mathrm{~mm} \mathrm{day}^{-1}(42.7 \%)$ & $2.8 \mathrm{~mm} \mathrm{day}^{-1}(37.9 \%)$ & $0.3 \mathrm{~mm} \mathrm{day}^{-1}(48.4 \%)$ \\
\hline 50 & $0.5 \mathrm{~mm} \mathrm{day}^{-1}(41.9 \%)$ & $4.8 \mathrm{~mm} \mathrm{day}^{-1}(36.4 \%)$ & $0.5 \mathrm{~mm} \mathrm{day}^{-1}(47.6 \%)$ \\
\hline 60 & $2.2 \mathrm{~mm} \mathrm{day}^{-1}(23.9 \%)$ & $5.0 \mathrm{~mm} \mathrm{day}^{-1}(15.9 \%)$ & $1.4 \mathrm{~mm} \mathrm{day}^{-1}(33.4 \%)$ \\
\hline 70 & $4.2 \mathrm{~mm} \mathrm{day}^{-1}(23.9 \%)$ & $4.0 \mathrm{~mm} \mathrm{day}^{-1}(15.9 \%)$ & $1.1 \mathrm{~mm} \mathrm{day}^{-1}(33.4 \%)$ \\
\hline
\end{tabular}

Source: Secondary data by Simulation of UPLOW model (2015)

The ideal level of water table is at $50-100 \mathrm{~cm}$ and this depends on the type of crops, and soil texture. In this case, water table data was found at $20 \mathrm{~cm}$ below soil surface during the initial stage. At this level, the capillary water movement is sufficient to fulfill crop evapotranspiration. Generally, at development stage crops can be grown on soil water depth of 1.5-2.0 m. However, if the ground water level at $50.0 \mathrm{~cm}$ depth under soil surface, all the crop water needs can be met by ground water through capillary rise. The field experiment was conducted during wet condition and the water level during vegetative stage was 50 $\mathrm{cm}$ below soil surface and continued till Journal of Wetlands Environmental Management Vol 8, No 1 (2020) 1 - 10

http://10.20527/jwem.vol 8 No 1.211 generative stage in May 2015. Most of crop water requirements could be achieved by ground water through capillary rise when the ground water level at a depth of $0.5 \mathrm{~m}$ (Antonelli et al., 2015). In sunflower case, when it was grown under clay soil texture, crop water requirement was enough from capillary rise at soil water depth of 150 to $200 \mathrm{~cm}$ under soil surface. In this condition, water requirement of sunflower could extract $92 \%$ of the available water.

The planting period of watermelon was after paddy harvest time (from Mid-March to May). It did not need irrigation because there was a lot of rain. The tertiary gate was operated maximum drainage during growing 
period. Thus, the water management objective in this season was maximum drainage.

Micro water management in tertiary block is developed in a quarter channels. This channel is perpendicular to the tertiary channels, and at the mouth of the channel quarter makes water valve gate. This channel is immediately supply and or drain water from the tertiary block. In a land plot of the water system consists of a collector and a quarter channels (channel worms). Collectors around the land that store temporarily accommodate drain water from the worm channel. Worms channels were created by the inter channels with spacing of $6-8 \mathrm{~m}$; the depth was $15-20 \mathrm{~cm}$ and the width of $50 \mathrm{~cm}$ (Fig. 4).

Harvesting time of water melon in May, could promote the third crop cultivation. The third crop was planted in June. However, the crop in the generative period (July-August) will get water deficiency and the farmer should apply pump irrigation to water the crop.

\section{Water Management for Watermelon Cultivations under Wet Condition}

The watermelon was planted in March 2015 , it was still raining and the land was waterlogged. The water table was reduced by making micro drainage system with the inter-channel spacing of $8 \mathrm{~m}$ and a depth of $20 \mathrm{~cm}$. This drainage concept was a shallow drainage method since it was easy, economical and the depth of the channel would not create a layer of pyrite oxidation. It can also be applied for paddy cultivation.

Based on the observations made, it indicated that the condition of the tide occurred at 10:00 AM until 02:00 PM, its height was $130 \mathrm{~cm}$ and $165 \mathrm{~cm}$. It caused a lot of water entering the field, especially if there was a high rainfall. Fig. 5 shows the duration of water level decreases during the low tide within 6 hours. The maximum receding water conditions in the secondary channel occurred at 6:00 to 08:00 AM and lasted for only 3 hours with a water height of $60 \mathrm{~cm}$. The discharge of water in the soil was not sufficient to be drained (Fig. 5).

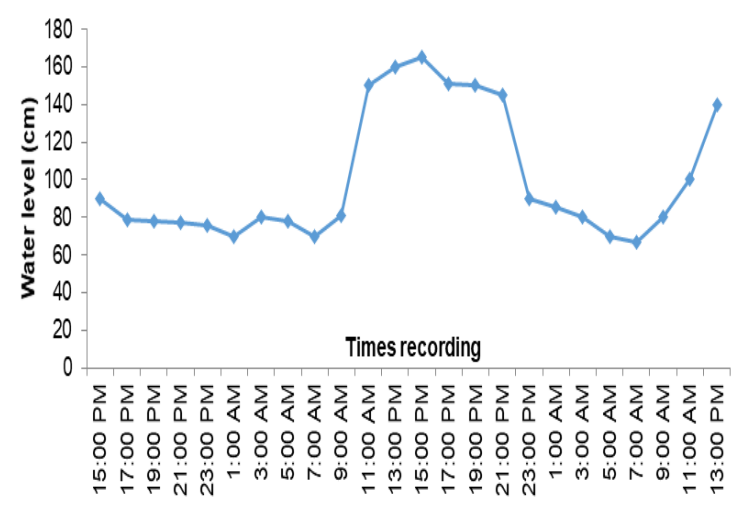

Figure 5. Fluctuations of surface water in secondary channel in the Mulyasari village

Watermelon crops were planted on an area of 0.5 ha in mid-March 2015. Ponska (dose of $400 \mathrm{~kg}$ ) and Mutiara fertilizers (dose of $150 \mathrm{~kg}$ ) were divided into 5 times application during growing period. The fertilizers were mixed with the water to make them easily absorbed by the crop and then five time sprayed on the land of watermelon. Harvesting time was done in mid-May. The productivity was reached in average $20 \mathrm{t} \mathrm{ha}^{-1}$ (Fig 6.). The profit obtained in one hectare ranged 25-30 million rupiah.
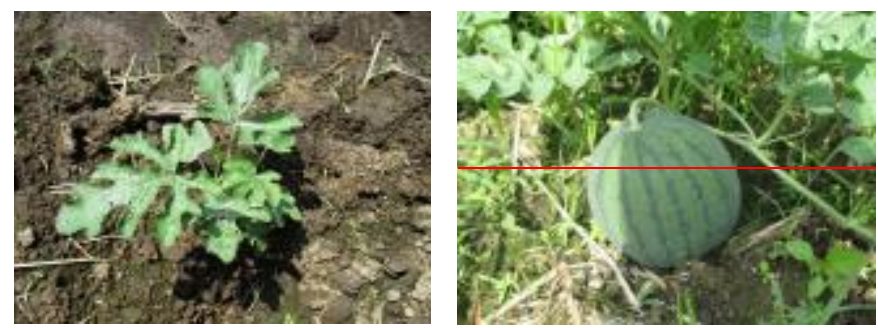

Figure 6. The performance of water melon growth in tidal lowland under wet condition

The productivity was lower than the maximum national productivity that can reach around $30-40 \mathrm{t} \mathrm{ha}^{-1}$. It was caused by the excessive water status and the water table depth on average of groundwater table was in 
15-20 $\mathrm{cm}$ below the soil surface. It induced provide enough crop opportunity to take that the soil was too wet for crop growth. water from the shallow water table. The Micro drainage in tertiary block was not maximum root depth to water was an working properly to reduce the water table, average water depth of $>50 \mathrm{~cm}$ (Ayars et al., because the macro drainage system (secondary 2006).

canal) did not have enough time to drain water during low tide. Thus, the modified planting time is the best way to avoid excess water due to very shallow ground water table. Based on the water table fluctuation data (Fig 7) showed that in the beginning of dry seasons (AprilMay) was good possibility to start planting. The groundwater table level was $25 \mathrm{~cm}$ in average. It was very suitable for water melon growth in the initial stage (Imanudin et al., 2019). Since the stress water could be done during the generative period (July), and then the pumping irrigation would be required. It was also that the water table should be maintained under $50-70 \mathrm{~cm}$ below soil surface to avoid pyrite oxidation.

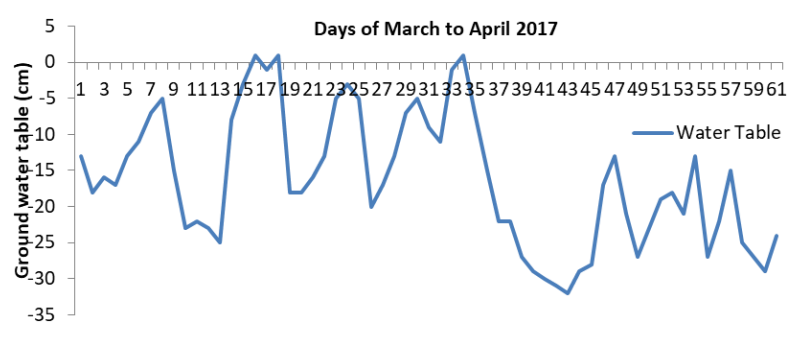

Figure 7 . The daily water table fluctuation in the field

The decreasing production of watermelon was caused by the excess water and also followed by other crops such as corn. Imanudin et al. (2010) reported that the corn planted in wet conditions (March to May) had around $30 \%$ of result reduction compared to normal production. The range values in the optimum water table depth were ca. 100-150 cm, where corn yields reached the highest yield and stable. A corn yield with deep water level of $>400 \mathrm{~cm}$ was highly reduced to a quarter and half of results in comparison to those in areas with optimal water table conditions. The number of days for a full root growth to total growth period should be $<0.5$. This condition is able to Journal of Wetlands Environmental Management Vol 8, No 1 (2020) 1 - 10 http://10.20527/jwem.vol 8 No 1.211

\section{CONCLUSION}

Developing drainage system in micro level of tertiary plot is very important to implement second crop cultivation under shallow water table condition on tidal lowland reclamations area. Water table at initial stage can be maintained at $25 \mathrm{~cm}$ below soil surface. The water melon planted at mid-March was successfully growth and harvested in May with $20 \mathrm{t} \mathrm{ha}^{-1}$ production. This production is still low due to the excess water in the generative stage. The best planting time is in April to avoid excess water during the initial and generative phase.

Tertiary gate of valve gate fiberglass type was suitable to maintain ground water table in tertiary canal. The gate should be installed in awhole area when the second crop was planted after rice at one secondary areas (250 ha). Gate operation model in the tertiary canal was as drainage option during vegetative period (April-May) and supply during the generative phase (July to June).

\section{ACKNOWLEDGEMENT}

The authors wish to acknowledge the financial supports provided through Competitive National Strategy Grant Scheme Nr. 514/SP2H/PP/DP2M/VII/2009 on 24 July 2016 by DIKTI of National Education Ministry, Jakarta.

\section{REFERENCES}

Aswandi, Susanto, R.H., Saleh, E., Abdillah, M.R, Iskandar. 2017. Simulation of CO2 Emission and Land Subsidence in Reclaimed Tidal Peat Swamp in Berbak Delta, Jambi, Indonesia. International Journal of GEOMATE, Jan., 2017, Vol. 12, Issue 29, pp. 186 - 194 
Antonelli, J., Lindino, C. A., Santos, R. F., de Souza, S. N. M., Nadaletti, W. C., Cremonez, P., \& Rossi, E. (2015). Sunflower culture response under different water table depths. Food, Agriculture and Environment, 13(2), 259-261. Retrieved from http://worldfood.net/sunflower-culture-responseunder-different-water-table-depths/

Asri, A. C., Sutanto, A., \& Ruslanjari, D. (2012). Studi komparatif pendapatan petani semangka dan petani padi (Studi kasus Desa Pilang dan Desa Sidodadi Kecamatan Masaran Kabupaten Sragen) [Comparative study of farmer income of watermelon and farmers rice (Case study Pilang Village and Village Sidodadi Masaran District of Sragen]. Jurnal Bumi Indonesia, 1(3), 156-162. Retrieved from http://lib.geo.ugm.ac.id/ojs/index.php/jbi /article/view/80

Ayars, J. E., Christen, E. W., Soppe, R. W., \& Meyer, W. S. (2006). The resource potential of in-situ shallow ground water use in irrigated agriculture: A review. Irrigation Science, 24(3), 147-160. http://doi.org/10.1007/s00271-0050003-y

Barzegar, T. , Hadi. L., Vali. R., Zahra. G., and Jafar. N. 2017. Effect of waterdeficit stress on fruit yield, antioxidant activity, and some physiological traits of four Iranian melon genotypes. Iranian Journal of Horticultural Science. 13(25), 13-25. http:DOI: 10.22059/ijhs.2017.63643

Bonaiti, G., \& Borin, M. (2010). Efficiency of controlled drainage and subirrigation in reducing nitrogen losses from agricultural fields. Agricultural Water Management, 98(2), 343-352. http://doi.org/10.1016/j.agwat.2010.09.0 08

Erdem, Y., Erdem, T., Orta, A., \& Okursoy, H. (2005). Irrigation scheduling for watermelon with crop water stress index (CWSI). Journal of Central Europian Agriculture, 6(4), 449 - 460. Retrieved from

https://jcea.agr.hr/volumes.php?search= Article\%3A284

Helmers, M., Christianson, R., Brenneman, G., Lockett, D., \& Pederson, C. (2012). Water table, drainage, and yield response to drainage water management in southeast Iowa. Journal of Soil and Water Conservation, 67(6), 495-501. http://doi.org/10.2489/jswc.67.6.495

Imanudin, M.S., M. E. Armanto, Bakri. 2019. Determination of planting time of watermelon under a shallow Groundwater table in tidal lowland agriculture areas of South Sumatra, Indonesia. Irrigation and Drainage Journal 68(3): 488-495p.

Imanudin, M. S., Armanto, M. E., Susanto, R. H., \& Bernas, S. T. (2010). Water status evaluation on tertiary block for developing land use pattern and water management strategies in acid sulfat soil of saleh tidal lowland reclamation areas of South Sumatera. AGRIVITA Journal of Agricultural Science, 32(3), 241-253. http://www.agrivita.ub.ac.id/index.php/a grivita/article/view/16

Nosetto, N. D., Jobbágy, E. G., Jackson, R. B., \& Sznaider, G. A. (2009). Reciprocal influence of crops and shallow ground water in sandy landscapes of the Inland Pampas. Field Crops Research, 113(2), 138-148.

https://doi.org/10.1016/j.fcr.2009.04.016

Raes, D., de Nys, E., \& Deproost, P. (2002). UPFLOW, a model to assess water and salt movement from a shallow water table to the topsoil. Paper presented at Proceedings of the Actes de l'atelier $d u$ PCSI, Montpellier, France, 28-29 may (pp. 1-9). Retrieved from https://www.academia.edu/8366558/UP FLOW_a_model_to_assess_water_and salt_movement_from_a_shallow_water table to the topsoil

Schultz. B. 2016. Impacts of man-Induced Changes in Land use and Climate Change on Living in Coastal and Deltaic 
Areas. Paper presented in the Workshop on Environmental Impacts and Sustainable Management of Tidal Lowland Areas. 3 October 2013, Mardin, .Turkey.

Udom, I. J. Ugwuishiwu, B.O, Uram, R.I. 2013. Groundwater Contribution to Crop Water Requirement of Waterleaf (Talinum Triangulare) in Oxisols of
South-South Nigeria. Nigerian Journal of Technology (NIJOTECH) Vol. 32. No. 3. November 2013, pp. $424-432$

Zhu. G., Xu.X., Wang, H., Li., Feng, Z. 2017. The ecological cost of land reclamation and its enlightenment to coast sustainable development in the northwestern Bohai Bay, China. Acta Oceanologica Sinica. 36(4). Pp 97-104. 